\title{
An Intervention to Support Teachers in Building on Children's Home Literacy Backgrounds
}

\author{
Lilly M. Steiner \\ Monmouth University \\ West Long Branch, NJ \\ Christina Cassano \\ Salem State University \\ Salem, $M A$
}

\begin{abstract}
This study examines the results of a family literacy intervention to teach teachers to build on students' home literacy practices. A quasi-experimental design was used to study effects on: (1) the use of home-based literacy practices at school; (2) teachers' beliefs about the family's role in children's literacy development; and (4) first-graders' literacy achievement. The study was conducted in two first-grade classrooms with culturally diverse student populations. In the treatment classroom, the teacher learned practices for building home-school partnerships. This teacher incorporated specific opportunities to learn more about students' home literacy practices and involve parents in children's literacy learning that led to an increase in parent-teacher collaboration. A combination of teacher and parent participation in the intervention resulted in statistically significant differences in students' scores on the Concepts About Print (CAP) assessment compared to students in the control classroom. This study is small; yet, it provides a timely and relevant model to promote parent involvement, which is particularly important given the renewed emphasis on building effective home-school partnerships.
\end{abstract}

Improving children's literacy learning outcomes involves all parties in a child's education. Research has acknowledged the importance of home-literacy practices on children's school-based literacy development. Whereas some research has shown that when parents engage in school-like literacy activities (e.g., dialogic book reading), less is known about how children benefit when teachers incorporate and build on children's home literacy background. A child's home literacy background is operationalized as those adult-child interactions in the home that have contributed to a child's literacy development before they enter the classroom. These interactions can include 
such informal and formal home activities such as toy play (Dickinson \& Tabors, 2001), engaging in story time and conversations (Heath, 1983), and teaching children about reading and writing (Sénéchal \& LeFevre, 2002, 2014).

Studies have identified relationships between reading at home and the development of important early literacy skills, including: print knowledge (National Early Literacy Panel, 2008), familiarity with decontextualized language (Dickinson \& Tabors, 2001), oral vocabulary (Beals, DeTemple, \& Dickinson, 1994; Sénéchal \& LeFevre, 2002, 2014), and positive attitudes towards literacy (Baker, Mackler, Sonnenschein, \& Serpell, 2001). For example, Wade and Moore (1998, 2000) found that when parents interacted with books during infancy, the children outperformed their peers in both literacy and numeracy in elementary school. Englund and colleagues (2004) conducted a longitudinal study that demonstrated that mothers' literacy support when their children were 42 months old had a direct effect on children's IQ and school achievement in the first and third grade. In fact, parental interaction around literacy in the early years has been shown to be a more powerful predictor of children's literacy achievement than family background variables including social class, family size, or parental education (Flouri \& Buchanan, 2004).

Once children begin school, parent involvement during elementary school has also been shown to be important for children's literacy development (e.g., LeFevre \& Shaw, 2011; Van Voorhis et al., 2013). Jeyne's (2012) meta-analysis identifies statistically significant effect sizes for parental involvement school-based programs. These shared reading programs in which parents learned specific strategies for reading with children yielded the highest effect sizes, providing validation for those models that provide parents with instruction on how parents and children can best utilize their shared reading experiences. Specifically, when parents are involved, children tend to demonstrate higher levels of achievement and positive school behavior (Jeynes, 2012). Policy makers have long since recognized the importance of parental involvement. For example, the 1994 National Educational Goals Panel noted that parents have a "strong complementary role to play in their children's school learning and behavior" and recommended two-way conversations between schools and parents (United States Department of Education, 1996). More recently, Common Core State Standards have cited the role of parents in children's education, and states are requiring parental involvement to be a component of teacher evaluation (National Governors Association Center for Best Practices \& Council of Chief State School Officers, 2010). For example, in Massachusetts, teachers achieve a rating of proficient on the Family and Community Engagement standard by "[using] a variety of strategies to support every family to participate actively and appropriately in the classroom and school community" (p.10). Similarly, in California, parent involvement has been identified as one of eight "priority areas" by the state, and schools will be assessed as to how successful they are in working with parents (Thigpen, Freedberg, \& Frey, 2014).

Although the research on the benefits of parental involvement in children's education is clear; unfortunately, children's home literacy backgrounds vary considerably (Janus \& Duku, 2007; Landry \& Smith, 2012). For example, whereas some families engage in home literacy experiences that are consistent with school literacy practices, such as talking about letters/sounds (Sénéchal \& LeFevre, 2002, 2014; Silinskas et al., 2012) or asking questions about stories (Whitehurst et al, 1994), other families engage in practices such as storytelling that, although rich, are incongruent with school practices (e.g., Heath, 1983). Additionally, the home language spoken in the home may also affect the types of literacy activities occurring in the home. O'Donnell (2008) found that children were less likely to be read to at home when one or both parents did not speak English. Anecdotal evidence suggests that the lack of reading may result from the parents' fear 
that reading in the home language may inhibit children's learning of English in school (Ballantyne, Sanderman, \& McLaughlin, 2008).

Despite the longstanding importance of parental involvement in education, research on how teachers and parents, collaboratively, can develop and sustain partnerships that positively impact children's learning is needed. Complicating matters further, Epstein and Sanders (2006) found that pre-service teachers are frequently under-prepared for working constructively with parents, particularly those who are culturally and linguistically diverse and whose backgrounds differ from the teachers. One reason for this lack of training is that, in general, teacher education programs provide few opportunities for learning about home-school partnerships (Epstein \& Sanders, 2006; Sheldon \& Van Voorhis, 2004). When pre-service teachers enter the field, it is unlikely that they will develop this knowledge, as few chances exist for professional development in the areas of home-school partnerships (Epstein \& Sanders, 2006). Even if there were such opportunities, within the field of literacy, traditional professional development programs often have little impact on changing teacher beliefs or attitudes, and these shifts are necessary to change teacher practices (Morrow \& Casey, 2004).

Continued efforts to educate parents about school-based literacy instruction (e.g., Jordan, Snow, \& Porsche, 2000) and educate teachers on how to adopt culturally relevant teaching practices (e.g., Moll, Amanti, Neff, \& Gonzalez, 2005) are needed because little is known about how teachers learn from parents about home literacy practices and building on them in the classroom (Yaden \& Paratore, 2003), and developing effective parent-teacher collaboration is underspecified (Eberly, Joshi, \& Konzal, 2007).

This study is part of a larger investigation of how to create home-school partnerships between teachers and parents, in which both parents and teachers participated in separate interventions to promote strong home-school partnerships. The parent program resulted in positive changes in parents' home-literacy practices to incorporate more school-like literacies and impacted students' concepts about print (Steiner, 2014). The goal of the present study is to investigate the results of the teacher intervention and to examine changes in: (1) the ways the teacher incorporated her knowledge of children's home literacy practices into her instruction; (2) the teacher's beliefs regarding the role of parents as "the child's first teacher," particularly in the area of literacy; and (3) students' early literacy skills.

\section{Methods}

\section{Setting}

This study was conducted in a large, linguistically and culturally diverse public school district in the Northeast. Seventy-five percent of students receive free or reduced price lunch. Two schools within the district participated in the study. The treatment classroom was located in a school with the following student racial/ethnic distributions: Black: 52.7\%, Hispanic: $28.1 \%$, White: 17.4\%, Asian/Pacific Islander: 1.3\%, and American Indian/Alaska Native: 0.4\%. Enrollment totaled 224 students. The control classroom was located in a school with the following student racial/ethnic distributions: Black 45.9\%, Hispanic: $21.9 \%$, White: $23.3 \%$; Asian/Pacific Islander: 7.2\%; and Native American/Alaska Native: 1.7\%. Enrollment totaled 292 students. Both classrooms followed the same mandated literacy curriculum. 


\section{Participants}

Teachers. Two teachers volunteered to participate in this study. One was randomly selected to be the treatment teacher and the other served as the control. The treatment teacher was informed that there would be separate parent and teacher interventions in her classroom to serve dual purposes: (1) to teach parents how to incorporate school-based literacy practices, such as storybook reading and conversations surrounding books, into everyday routines; and (2) to instruct her in ways to recognize and incorporate existing home literacy practices into school-based literacy instruction. Her undergraduate and graduate degrees were in elementary education, and she had 14 years of teaching experience. She had taught in the district for eight years. There were 19 students in the treatment classroom; seven students identified as White, seven as Black, four as Hispanic, and one as Asian/Pacific Islander.

The control teacher participated in data collection measures, but not in the intervention. She held a dual undergraduate degree in elementary education and history and a graduate degree in urban education. She had been teaching for eight years, with six of these years were in this particular district. Among the 19 students in the control classroom, the teacher identified eight students as White, six as Black, four as Hispanic, and one as Asian/Pacific Islander.

Students. Data from students in both classrooms were also collected. From the treatment classroom, it was expected that some parents would elect to participate in the parent intervention and some would not. As a result, two conditions within the treatment classroom existed six students with both parents and teacher participating in the intervention, and thirteen students with the teacher participating, but not a parent. The 19 students in the control classroom had neither a parent nor a teacher participating in the intervention. The creation of these three conditions allowed for an examination of the differential effects on children's literacy that might occur across the groups.

\section{Study Design}

The present study employs a quasi-experimental, mixed-methodology model. The rationale of mix-method design is to use the various forms of data to respond to different aspects of the study goals. In particular, teacher interviews and classroom observations were used to determine the beliefs, attitudes, and classroom practices of the teacher participants (Patton, 2002). To determine effects on student learning, a pre-post, control group (intervention versus nonintervention) design was used.

\section{Teacher intervention}

The primary investigator (PI) met with the treatment teacher once weekly, for eight weeks, during the regularly scheduled 90-minute teacher-planning time. These sessions focused on building knowledge of students' home-literacy practices; and connecting the knowledge to classroom literacy instruction. Incorporated into the meetings were discussions of several articles (Valdéz, 1996; Moll, Amanti, Neff, \& Gonzalez, 2005) to promote understanding of home literacy and home-school partnerships. The PI and the teacher collaboratively developed connected activities to invite parents to be specifically involved in their children's school-based literacy learning. The teacher chose these activities based on her perceived area of need in this particular classroom.

The first initiative the treatment teacher implemented was to invite parents as classroom storybook readers twice weekly for eight weeks. As part of the initiative, she encouraged parents to read the story in either English or in the family's home language. When parents chose to share a book in Spanish, the child served as a translator to explain the book to other students. In addition, 
the teacher provided parents access to bilingual English/Spanish books (e.g., Moon rope/Un-lazo a la luna by Lois Ehlert).

Secondly, the treatment teacher chose to integrate an on-going project that incorporated family and community resources to utilize the "funds of knowledge" of those students and their families. These funds are defined as "the historically accumulated and culturally developed bodies of knowledge and skills essential for household or individual functioning and well-being" (Moll, Amanti, Neff, \& Gonzalez, 2005, p. 87). The goal of the project was to promote the teacher's knowledge of her students' households, and to learn how cultural and cognitive resources could be used in the classroom to develop culturally responsive and meaningful lessons. Specifically, she developed a four-week social-studies unit on families as part of the intervention that she and the student teacher designed and co-taught, which was informed by her knowledge of the students' families. The unit, which aligned with the curriculum state frameworks, had the following objectives:

Through the activities and discussions planned in the unit students will learn about each other's families, from the people who make it up to what they do together. Students' cultural backgrounds will be recognized and honored so that the uniqueness of each child's family is recognized. Lessons will also foster the understanding that the classroom works together as a family.

The following read-aloud books were selected for the unit: Who's in a Family? (Sketch, 1998); The Surprise Family (Reiser, 1994); Families (Morris, 2000); My Family (Kinkade, 2006); The Wednesday Surprise (Bunting, 1990); Celebrations (Kindersley, 1997); Tap, Tap (Williams, 1994). At the conclusion of the unit, families were invited to a celebration in which students' work was displayed and shared. Student activity sheets were compiled into a book from which students shared a favorite page with the families. Families were also encouraged to bring food, drinks, or a special artifact to share that was representative of their family or culture. Additionally, the students sang a song that was adapted from the poem, "What is a Family?" (Hoberman, 2001) and then taught it to the parents at the end of the celebration

Finally, the teacher and the PI collaboratively developed a 90-minute parent workshop (held after school), with the dual purpose of teaching parents about classroom literacy practices and helping the teacher learn about home literacy practices. In an effort to increase this knowledge, she and the PI collaboratively designed a parent workshop to demonstrate how children participated in literacy learning in the classroom. At the parent workshop, parents rotated throughout the reading centers and practiced literacy activities to use in the home that reflected those used by teacher. As part of the workshop, she also invited parents to share home-literacy practices. At the conclusion of the workshop, she provided parents with various classroom-based literacy activities to use at home (see Table 1).

Table 1. Parent attendance at literacy events in treatment classroom

\begin{tabular}{lc} 
Event & No. of parents attending \\
\hline Writers' celebration & 14 \\
Weekly parent read-alouds & 11 \\
Social studies family celebration & 14 \\
Parent workshop & 10 \\
\hline
\end{tabular}




\section{Data Sources and Collection}

\section{Teacher interviews}

The PI interviewed participating teachers on two occasions - once in a three-week period before the study began and again during a three-week period after it ended. The interview questions were adapted from Wigfield et al. (1997) and sought to obtain information on: (1) teacher-parent communication; (2) teacher's literacy goals for child; (3) classroom practices; and (4) beliefs about parent involvement (see Appendix A).

\section{Classroom observations}

The PI also conducted nine one-hour classroom observations in both the treatment and control classrooms. The first observation, which occurred one week before the intervention, provided baseline data on classroom practices. Thereafter, the PI conducted eight observations, once weekly. Observations focused on literacy instruction, including reading, writing workshop, and literacy-center time. Particular attention was paid to the ways the teachers and students referred to and utilized out-of-school experiences and the circumstances in which teachers used these experiences to inform classroom decisions. The PI focused on evidence of change related to the integration of home and school literacies in classroom literacy practices and teacher attitudes within both the treatment and control classrooms. To verify that the treatment and control teachers were at the same level at the outset of the study, the initial observations between the two classrooms were compared and instances of ways in which the teachers integrated cultural/home background into classroom literacy instruction were calculated. At the outset of the study, observations reveal that such instances occurred in neither classroom during the first observation, thus indicating that teachers were at the same initial level.

\section{Student literacy assessments}

In both the treatment and control classrooms, the PI administered the following assessment measures to determine changes in children's literacy learning: Concepts About Print (CAP) (Clay, 2003), Developmental Reading Assessment (DRA; Beaver \& Carter, 2006), and subtests from the Dynamic Indicators of Basic Early Literacy (DIBELS) (Good \& Kaminski, 2002), including lettername fluency (LNF), phoneme segmentation (PS), and the nonsense word fluency (NWF). These assessments were selected because they are frequently used in classrooms and by educational researchers to measure students' literacy skills in the areas central to early literacy achievement (Rathvon, 2004). Pre- and post-tests were administered in September and December, respectively, and shared with the teachers.

\section{Data Analysis}

A constant comparison method was used to analyze all teacher interview transcripts and classroom observations to determine the distinctive characteristics of identified data and enable placement in the appropriate categories (Charmaz, 1983; Gay \& Airasian, 2003). At the outset of the analysis process, transcripts from the teacher interviews and classroom observations were independently coded by at least one other researcher; codes were compared and agreement calculated. Differences were discussed and resolved, and the process of dual coding continued until greater than $95 \%$ agreement was reached on the coding of the two interview transcripts and four of the classroom observations. Only the PI coded the remaining interview and observation 
data. At the end of the study, $10 \%$ of the coded observation and interview data were randomly selected and re-coded by a third researcher who holds Ph.D. in child psychology. A 92\% agreement was reached, which verified consistent and appropriate use of codes throughout the analysis process.

A two-sample $t$-test was conducted for each assessment to determine students' baseline literacy performance in the treatment and control classrooms. Pre-test scores of students in the treatment and control classroom were compared to determine whether students were initially at the same level on the DRA, CAP and three DIBELS subtests (see Table 3). Post-intervention, a oneway analysis of variance (ANOVA) was used to determine whether the different intervention levels, (teacher only versus teacher and parent), would affect student performance. To study the intervention effects on students when only the teacher participated, two sample $t$-tests were conducted across the five assessment measures. When statistical significance was detected, an ANOVA was conducted on the three groups to compare the different levels of the intervention; otherwise, groups A and B (Classroom 1) were merged and then compared to Group C (Classroom 2) using two sample $t$-tests.

\section{Results}

The results of this study indicate that changes were evident in three areas: 1) teacher's knowledge of home literacy practices; 2) teacher's beliefs about parental involvement; and 3) children's early literacy achievement.

\section{Effects on Teacher Knowledge of Children's Home Literacy Practices}

Pre-intervention interviews demonstrated that both the treatment and control teachers primarily used school-initiated measures to provide parents with information about their children's education. Table 2 gives a more detailed description of school-based initiatives.

Table 2. School-based measures to provide parents with information about children's learning

\begin{tabular}{lll}
\hline Event & Treatment & Control \\
\hline Parent-teacher conferences & $\begin{array}{l}\text { Fall (two extra conferences for } \\
\text { students identified as striving) }\end{array}$ & Fall and spring \\
School newsletter & Monthly & Monthly \\
School information/ website & Yes & Yes \\
Introduction to classrooms & Parent breakfast & Open house \\
Math/literacy nights & One for each subject & One for each subject \\
Committees & $\begin{array}{l}\text { School Parent Council } \\
\text { (Parent members) }\end{array}$ & $\begin{array}{l}\text { School site council } \\
\text { (Parent/teacher } \\
\text { Paremts welcomed into }\end{array}$ \\
Family day & $\begin{array}{l}\text { Parembers } \\
\text { classroom once in fall }\end{array}$ & N/A \\
\hline
\end{tabular}


As part of the weekly intervention sessions, the treatment teacher learned that many parents, particularly those who were non-native English speakers or who attended school outside the United States, were unfamiliar with the language teachers use to describe their children's literacy learning. She compared the parent workshop she implemented to the district-initiated Literacy Night and explained:

With Literacy Night parents don't really see what the instruction looks like. Parents just see their [children's] work. They see their writing folder on the table or they see their "just right" book bag out and they see evidence of what they've done, but they don't work through it the way they did at the parent workshop.

The parent workshop initiated as part of the study enabled the teacher to promote parents' knowledge of their children's school-based literacy instruction by inviting them into the classroom. It also allowed her to assess parents' home-literacy practices and how she could help parents connect these practices to the instruction their children received in school.

As a result of her participation in the study, the treatment teacher reported that she began to initiate increased parent-teacher communication beyond the two required parent-teacher conferences. In particular, she maintained that she encouraged and conducted more frequent and personal parent-teacher meetings. The following is an example of how she collaborated with a father to address his son's fluency and comprehension:

I told him where [his child] was at with fluency and comprehension. He said, "I want him to read fast..." And I said, "You know, it's not really about fast. It's about fluency. Fluency doesn't mean fast. It means reading smoothly and understanding what he's reading. He's slow, but fluent, and understanding is not about fast." Then we talked about the whole thing. I tried to show him that [his son] doesn't need to read so fast... and he understood.

It appears that the teacher used these interactions to inform parents of how their home literacy practices could be changed, rather than how she could use the knowledge to extend and connect to home literacy practices. Yet, in another example, she explained how she worked with a parent to improve her daughter's reading achievement. This interaction increased the treatment teacher's understanding of the student's reading abilities, as the parent reported that her daughter willingly talked about books at home, whereas she rarely responded to books in class. The teacher stated, "[This student] got most improved in reading. Her mom wanted it so badly, and we worked so hard on reading together, mom and me, that [the student] will move on to the next grade." The teacher learned about this particular parent's goal for her child's literacy learning through one of these more spontaneous meetings, and in turn, learned more about home literacy practices, which helped to inform her classroom decisions.

Examination of classroom observation data also indicated other ways that that the treatment teacher began to use her classroom reading instruction as a time to gather knowledge about the home literacy practices of students in her classroom. She made specific goals to inquire about these practices during pre-reading instruction when she assessed or built children's background knowledge about the particular text. For example, a classroom observation revealed that before reading a particular book during the social-studies unit, she asked the students to complete a concept web titled, "Things families do together." A student, whose mother participated in the 
parent intervention, contributed by stating, "Families read together." The teacher then asked the child to name some of those particular books and that she and her mother read.

Additionally, the parent read-aloud sessions allowed the treatment teacher to obtain information about home literacy backgrounds of students in her classroom. During one observation, a parent read If You Give a Pig a Pancake (Numeroff, 1987). Three students made a connection to If You Give a Mouse a Cookie (Numeroff, 1985) - a book they acquired through their parents' participation in the parent intervention. The teacher then asked the students to briefly describe their connections before the parent read. Classroom observation data shows changes in how the treatment teacher used her knowledge of home literacy practices in various components of literacy instruction, such as guided reading, whole-group reading instruction, and writer's workshop. For example, during the sixth week of the study, she met with a guided reading group and asked students to generate predictions before reading. The focal book Big and Small (Trophies, Harcourt School Publishers, 2011) featured a picture of a dog on the cover. The teacher asked one reluctant speaker, Vanessa, to generate a prediction. The following excerpt details this pre-reading conversation:

Teacher: I know you have a dog at home. Is he big or small?

Vanessa: Big.

Teacher: What kind is he?

Vanessa: A rott [weiller].

Teacher: Oh my! He is a big animal. Let's look at the cover. It is called Big and Small. Is a dog an animal?

Vanessa: Yes.

Teacher: Can you find me the words animal and big? Let's do a picture walk.

After the guided reading session, the treatment teacher told the student teacher: "I am going to talk to Vanessa's mom, and we can work on making predictions with Vanessa at home."

During an observation from week eight, the treatment teacher again used her knowledge of students' background to promote a conversation during a guided-reading lesson with two students, Selma and Carrie. In the following example, she used the Thanksgiving holiday to promote a conversation. She then drew on this conversation to transition to the book they were reading:

Teacher: Girls, good morning. Did you have a nice Thanksgiving? Tell me what you did. Carrie: It was raining. We stayed inside.

Teacher: It did rain a lot! We also had to stay inside. Where did you go?

Selma: We went to two places.

Teacher: Was it your grandmother's? Where do they live? Is it your mommy's mommy or daddy's mommy?

Selma: Daddy's.

Teacher: Who cooked?

Selma: Grandma.

Teacher: [To Carrie] I know your mommy didn't eat the turkey. She told me she doesn't like it. Carrie what did you have?

Carrie: Ham.

Teacher: I love ham.

Selma: We also had dessert. 
Teacher: Did you have dessert [to Carrie]?

Carrie: Yes.

Teacher: I knew your mommy would make dessert, she told me she would. I am so glad you told me about your Thanksgiving. Speaking of going out to play, we are going to read a book about playing at home. It's called Going Outside to Play. What do you predict it is going to be about?

At the end of the session, she told both students, "We had such a good conversation today!" Following the session, she reported that she was in close contact with the parents of both these students. When asked to comment on the pre-reading conversation, she replied that these two students liked sharing what they did at home, and she used these conversations to prepare them to talk about the books they would be reading. The parent read-aloud sessions, which the teacher called Mystery Reader, also allowed the treatment teacher to link instruction to home literacy backgrounds of her students. For example, during week four, a parent who was not participating in the intervention chose to read Imogene's Antlers (Small, 1985). One student, Rosa, stated, "I have that book. I read it with my mom." The treatment teacher later commented on this remark to the student, and said that she could tell her mother was reading with her at home.

Finally, there was evidence that the treatment teacher began to use parents' suggestions in instruction. During one observation, she explained to the student teacher that after speaking to some parents earlier in the week, she had changed her protocol for choosing spelling words. Instead of sending words home only at the beginning of the week, she began to send information throughout the week to help parents prepare their children for the test, such as advice on how to use sentences, student writing, or books to practice spelling words. In the post-intervention interview, the treatment teacher shared an instance in which a parent made a suggestion regarding one of the reading centers, Sentence Maker. She reported that this suggestion prompted her reconsider its purpose and make it "more meaningful." Instead of having students simply form sentences out of word strips, as they had in the past, students were instructed to form sentences, read them to one another, and record them in their writer's notebook.

Similar interactions or connections to students' home literacy experiences were not evident in observation or interview data obtained from the control teacher. This teacher did not host any parent events during the intervention period aside from the required open house, which four parents attended. In the pre-intervention interview, the control teacher reported that she joined the study because she was also interested in increasing parental involvement in the classroom. Although she reported an "open-door policy" to engage parents in their children's school-based literacy learning, she found that parents rarely came to the classroom nor did they offer suggestions about her teaching. The control teacher maintained that the best way for parents who worked full time or had inflexible schedules to stay involved with their children's education was to "check homework, at the very least or read with them at bedtime." In an effort to involve parents in their children's literacy learning, she sent home a reading log and a daily contract that she developed to provide parents information on children's conduct, effort, and achievement. The contract also provided a homework list and a place for parents to sign when they helped with homework. Finally, in the initial interview she stated that in the past, she integrated parent events into the literacy curriculum, particularly around writer's workshop, and reported that she hoped to integrate at least two such events during the period of the study.

In the post-intervention interview, the control teacher reported that parents responded well to the school contract she sent home, but that parents often returned the reading log incomplete. 
She explained, "It is supposed to be part of the homework, and some kids do it but about four kids never do it...It just doesn't get done." To follow up with parents of these students, she circled an incomplete on the homework and wrote, "No reading log." However, she stated that incomplete homework did not prompt her to call or schedule parent conferences. She also reported that she did not provided any additional support to parents on how to read with their children at home or information about how she taught reading to students. At the end of the study she hosted the required open house event, but "had not gotten to" the intended parent events that she initially reported that she would host.

\section{Effects of the Intervention on Teacher Beliefs}

Analysis of interview and classroom observation data were examined to reveal any changes in how the treatment and control teacher connected students' backgrounds and home literacy experiences to school-based literacy practices. Interviews also elicited teachers' perceptions of how they incorporated students' home literacy backgrounds into school-based literacy instruction. These perceptions were viewed in light of practices identified though classroom observations.

Analysis of teacher interviews indicated changes in the treatment teacher's beliefs about parents' role in their children's literacy learning. Likewise, efforts to invite parents as classroom participants led the treatment teacher to view parents' role in their children's literacy learning as a two-way relationship in which both parties collaborate and contribute to the children's learning. For example, she reported that in the past, parents rarely offered suggestions about her instructional practices; however, when provided an opportunity to so, such as during the parent workshop, the treatment teacher found parents were inquisitive about why she engaged students in specific practices. She stated, "I thought it was interesting that one parent said, "And so, do you go strictly by the Trophies [reading curriculum]?' (Harcourt School Publishers, 2011). That was kind of a smart thing, but I wasn't expecting them to be that 'with it'." She also found that this kind of dialogue allowed her to explain how she used observation and literacy assessment to inform her instructional decisions. She told parents that the reading curriculum provided the scope and sequence, but explained, "If [students] need something more, I do something else." She explained how a parent response conveyed to her the extent of their understanding about literacy instruction:

Then another parent said, "And so you're in here by yourself to do \{this \}?" And I said, "Well, no, [the student teacher] is here, but she's going away in December." And they said, "Well, how are you going to do it?" And I think it's interesting that parents even think about that.

Overall, after participating in the intervention, the treatment teacher showed a change in her view on parents' role and involvement in children's literacy learning by inviting parents into the classroom. Pre-intervention, she stated her initial goals for participating: "I want to see how to bring parents in. I have tried a lot of things to get them in and hook them to be participants in their children's learning." This choice of words indicates that she may have believed that parents generally were unmotivated or unaware of how to participate in their children's literacy learning. By inviting parents into the classroom, she began to learn the extent of parental participation in children's learning and response to her classroom practices, as evidenced through her description of the parent workshop. She stated: 
It was scary, opening a classroom to parents and letting them really see what happens. There's nothing to hide, but to let them really see what you do and then having them ask you questions why you do it and kind of challenging you and questioning you about what you do. I actually... didn't think through that, I didn't think they would do that.

Analysis of pre- and post-intervention teacher interviews show a change in the treatment teacher's attitude towards parent-teacher communication. In the pre-intervention interview, she reported that she was comfortable communicating with most parents, but believed that only one or two parents were comfortable communicating with her. During the post-intervention interview, she stated that parents were more comfortable communicating with her, which in turn, increased her familiarity with home literacy practices of her students. For example, she described her experience with one father. During conferences, she had learned that he assumed all responsibility for helping his son with homework and was the only one to read to him. She said he told her, "This is my first child. I don't know if I'm doing this right. I'm alone and sometimes I don't know what to do." She explained that she tried to make him more comfortable while she shared information because she was more comfortable:

[He] gets nervous, too. One minute you can see him closed off because you've said something. And then the next minute, I said, "You know, Joseph has done a great job." And he's moved from this [level to this level], he [can work independently] for a little while longer - two or so minutes - than he used to before," and I can see Joseph smiling. I said, "You know, Joseph, that's a good thing and you should smile and be proud," and so at that point, his daddy kind of loosened up, and [we kept talking].

In particular, she noticed that parents who attended classroom events were more comfortable asking questions, asking for strategies for working with their children with homework, and talking about "what was working or not working at home." However, when asked to evaluate how comfortable all of the other children's parents were in contacting her, she replied, "I think pretty comfortable... They are really now at ease."

Interview data from the control teacher indicated no changes in her beliefs and attitudes about parents' role in children's literacy learning. From the pre-intervention interview to the postintervention interview, she primarily relied on written communication through a daily contract for information about their children's conduct and homework. Furthermore, she reported that parents were comfortable communicating with her; however, she reported no increases in the frequency of parent-teacher communication.

\section{Effects of the Intervention on Students' Early Literacy Skills}

Pre-test scores of students in the treatment and control classroom were compared to determine whether students were initially at the same level on the DRA, CAP, and three DIBELS subtests using a two-sample $t$-test on pre-test scores from students in the treatment and control classrooms. $P$-values of the $t$-tests were all greater than $5 \%$ indicating that students in the two classrooms were at the same initial level of their assessment performance on the DRA, CAP, and three DIBELS subtests. Table 3 presents the $p$-values of the pre-test scores between the treatment and control classrooms. 
Table 3. P-values of pre-test scores between treatment and control classrooms

\section{DIBELS}

\begin{tabular}{llllll}
\cline { 4 - 5 } & CAP & DRA & LNF & PS & NWF \\
\hline Pre-test & .481 & .326 & .506 & .418 & .066
\end{tabular}

$\mathrm{CAP}=$ Concepts About Print $; \mathrm{DRA}=$ Developmental Reading Assessment $;$ DIBELS=Dynamic Indicators of Basic Early Literacy; LNF=letter-name fluency; PS=phoneme segmentation; NWF=nonsense word fluency.

Within the treatment classroom, the first treatment group, Group A, comprised students whose teacher participated in the intervention. The second treatment group, Group B, comprised students whose teacher and parent participated in the intervention. The control group, Group C, comprised students for whom neither teacher nor parents participated in the intervention. The treatment classroom is referred to as Classroom 1 and the treatment classroom as Classroom 2.

A one-way ANOVA was conducted on the three groups to compare the different levels of the intervention; otherwise, groups A and B (Classroom 1) were merged and then compared to Group C (Classroom 2) using two sample $t$-tests. A significance level of .05 was used. Statistically significant differences were not evident on children's scores on the DRA or DIBELS from either the treatment or the control classrooms.

A two-sample $t$-test was conducted to determine whether there was a statistically significant difference on mean performance post-test scores on the CAP of the students in the two groups in Classroom 1. The $t$-test yielded a $p$-value of .03 , demonstrating that when both teacher and parent participated in the intervention, students' scores on the CAP were significantly higher than for students for whom only the teacher participated in the intervention. Next, scores for Group A and Group B were compared to Group C, using a one-way ANOVA to test whether the two different intervention levels in the treatment classroom led to significantly different post-CAP scores compared to the control group. A $p$-value of .06 indicated that the three groups' post-test scores did not differ significantly (Table 4).

Table 4. One-way ANOVA for groups A, B, and C on post-test CAP scores

\begin{tabular}{lllllll}
\hline & df & SS & MS & F & $\mathbf{p}$ & $\boldsymbol{\eta}^{2}$ \\
\hline Between groups & 2 & 17.76 & 8.88 & 2.98 & .064 & .85 \\
\hline Within groups & 35 & 104.24 & 2.98 & & & \\
\hline Total & 37 & 122.00 & & & & \\
\hline
\end{tabular}

The insignificant $p$-value of .064 was reexamined using a post-hoc test based on the Least Significant Difference (LSD) to screen for group differences that existed due to sampling error. The post-hoc test on the post-test CAP scores for each pair of the three groups revealed a statistically significant difference. That is, there is sufficient evidence to show that the combination of teacher and parent participation in the intervention, as well as teacher participation in the intervention alone, improved children's CAP scores, compared to children in the control classroom (see Table 5). 
Table 5. Scores on post-test CAP for treatment groups A, B and control group (Post-Hoc Test)

\begin{tabular}{llcc}
\hline Group & Group & $\begin{array}{c}\text { Mean } \\
\text { difference }\end{array}$ & $\mathbf{p}$ \\
\hline Control & Treatment A & -0.55 & 0.185 \\
& Treatment B & -2.14 & 0.005 \\
Treatment A & Control & 0.55 & 0.185 \\
& Treatment B & -1.59 & 0.032 \\
Treatment B & Control & 2.14 & 0.005 \\
& Treatment A & 1.59 & 0.032 \\
\hline
\end{tabular}

\section{Discussion}

This study found that when teachers are provided with opportunities to learn how to learn from parents about the literacy practices occurring in the home, they are able to employ practices to involve parents meaningfully in their children's literacy learning. Delgado-Gaitan's (1990) study of Mexican immigrant families demonstrates that regardless of differences in the literacy instruction that high- and low-level Hispanic students received, these students were not invited to connect literacy learning to their language and literacy backgrounds. In this study, the teacher's change in practices to incorporate students' backgrounds into literacy instruction revealed a shift in her beliefs about the role of students' home and literacy backgrounds in promoting their literacy learning. These efforts led to the formation of stronger home-school partnerships that can positively affect children's learning. According to Dearing, Kreider, Simpkins, and Weiss (2006), there is increasing evidence that high levels of family involvement in schools are associated with high levels of child literacy achievement. Moreover, developing teachers' understanding of how to involve parents meaningfully in their literacy learning and as partners in their children's literacy plays an important role in creating effective home-school partnerships.

Unfortunately, developing these partnerships remains complex and involves multifarious factors. Numerous barriers hinder the formation of effective partnerships, including differences in the beliefs and attitudes of parents and teachers about parents' roles in children's literacy learning (McCarthey, 1997), limited time for parent-teacher communication, schools' lack of funding, schools assuming a passive role, and teachers' lack of training in how to work with families as partners (Turner \& Edwards, 2009).

This study was designed in recognition of these barriers and in an attempt to alleviate their adverse effects and promote positive outcomes by mediating teachers' knowledge about how to promote strong home-school partnerships. Moreover, this exploratory study validates an intervention model that increases the teacher's knowledge of how to involve parents in the classroom. Dodd and Konzal (2002) argue, "Since no one knows everything or has all the answers, everyone needs to work together to find better ways to educate children. And everyone has knowledge to contribute to this ongoing process" (p. 290). Throughout the intervention period, the treatment teacher initiated efforts to invite parents as classroom participants. Such efforts led to changes in how the treatment teacher viewed parents' role in children's literacy learning. At the end of the study, she characterized her relationships with parents as two-way in which both parties collaborated, exchanged, and contributed to children's learning. Yet, also within the study, it was evident that the treatment teacher continued to view interactions with parents as a means to help support their work at home around literacy. This finding indicates that the teacher believed this 
goal was more important than learning from parents about literacy practices already occurring and how to build on those in her classroom literacy instruction.

In an examination of the literature on family and community involvement on children's literacy learning, Sheldon and Epstein (2005) stated, "Historically most parents have been left on their own to create a supportive home environment for reading and literacy, even in infancy and the earliest grades" (p. 18). They concluded that such practices lead to inequities between parents who are more familiar with school-based practices and those who need explicit support in learning how to remain involved in their children's education. In addition to providing parents knowledge of school-based literacy practices, this study recognizes that teachers require support in providing parents specific opportunities for learning about classroom literacy practices. As a result of the support provided through the study, the treatment teacher began to integrate home literacy repertoires into literacy instruction, while providing parents with an increased understanding of classroom literacy practices. In this study, not only did the teacher build knowledge of classroom practices that could be used at home, she also provided opportunities for parents to share information about their own home practices.

Furthermore, because the teacher increased her interactions with parents, they may have viewed her as more approachable and helpful. Ames, Khoju, and Watkins (1993) reported that when parents perceive they are receiving frequent and positive messages from teachers they tend to become more involved in their children's education than parents who do not. The teacher's initiation of frequent, less formal conferences with parents before and after school may have resulted in a relationship that parents viewed as more of a partnership and less like a "professionalclient" relationship (Wells, 2004).

In this study, the effects of this intervention resulted in a modest impact on students' early literacy achievement-primarily affecting students' concepts about print, as indicated by statistically significant differences on the post-test CAP scores between students in the treatment and control classrooms. Other studies have noted similar findings on storybook reading and its effects on children's concepts about print (Purcell-Gates, 1996; Sénéchal, \& LeFevre, 2002). Children in the treatment classroom demonstrated statistically significant differences in the CAP, which is predictive of children's later literacy achievement (Clay, 2003). Similar results were not evident on DRA or DIBELS scores between students in the treatment and control classroom; therefore, this study shows that combination of teacher intervention and parent participation, as well as teacher intervention alone, played an important role in improving children's CAP over the scores of those students in the control group. This indicates that while it is important for teachers to engage in efforts to build collaborative relationships with parents, it is also important for parents to engage in efforts to learn more about their children's school-based literacy instruction.

As the school year progresses, it may be assumed parent-teacher partnerships will inherently develop. Although this study was small, involving work with one teacher in the treatment classroom, the use of a second teacher who served as a control demonstrated that the formation of a home-school partnership is not guaranteed as the school year continues. The control teacher believed she had an open-door policy, yet between the period of initial and final data collection, she reported no change in parent-teacher relationships or the frequency of parentteacher communication.

Teacher evaluation systems strive to promote teachers' roles in forming effective homeschool partnerships by expecting teachers to collaborate with parents. One reason for this emphasis is that we know parental involvement makes a difference (Jeynes, 2012; Van Voorhis et al., 2013; Steiner, 2014). As this study demonstrates, the teacher's participation in the intervention helped 
her to learn and incorporate the home literacy practices of her students into classroom instruction, as well as promote parent-teacher communication. These efforts to increase parental involvement had a modest impact on students' learning (as evidenced by scores on the CAP). However, when both a parent and a teacher participated in the family-literacy intervention the improvement increased. This reciprocal approach in which teachers and parents exchange information has the potential to support children's literacy learning at both home and school.

The goal of providing opportunities to work with parents is a first step. However, implementing an effective model that brings about changes in beliefs, which is more likely to affect changes in practice, is more complex. Professional development models that feature a brief and confined day for teachers to learn have been largely unsuccessful (Morrow \& Casey, 2004). The design of the present intervention model provides multiple opportunities for teachers to concurrently increase their knowledge of children's home literacy backgrounds and work closely with parents in ways directly connected to literacy instruction. As a result, the teacher learns ways for parents to become meaningfully involved in classrooms. In this study, the teachers worked directly with a university researcher. Applied beyond this study, this model could employ the use of a reading specialist or literacy coach who could work with one teacher or a group of teachers in a school, depending upon the school's need. Morrow, Casey, and Haworth (2003) suggest that the use of a reading coach, among other supports, such as administrative encouragement, can result in professional development that is both collaborative and effective in bringing about changes in practice. Yet, current practice dictates literacy specialists and coaches may not receive the support needed to promote home-school partnerships. It may also bear mentioning that teachers within the school be trained to support other teachers in a leadership capacity. Because members within the school are instrumental in designing an approach that is unique to their community, effects to create strong home-school partnerships may be sustained further.

\section{Limitations and Conclusions}

This study is a small one, working with only two teachers-because the study included only one control teacher, it is possible another teacher may have acted differently. Moreover, these teachers were particularly motivated to learn measures to improve home-school partnerships, which may have also influenced the outcome of this study. It is likely not all teachers would be motivated to participate at this level to build home-school connections. Substantial resources, including time and personnel, would be needed to implement this study on a larger scale, and some teachers may believe the extra time and efforts would be better directed elsewhere.

However, in this exploratory study, the use of a small sample allowed the researchers to closely investigate the practices and beliefs of teachers over a period of time that result in both the formation and barriers to home-school partnerships that may have gone unnoticed in a larger study. This knowledge could then inform the design of a larger study and help researchers anticipate areas of need and potential impediments.

The role of parental involvement in school-based literacy learning is a vital one. Moreover, we know that reciprocal partnerships between teachers and parents are evident in cases in which strong home-school partnerships exist (Epstein \& Sanders, 2006). As classrooms become more culturally and linguistically diverse, recognizing how to work with parents as partners will become increasingly challenging, provided teachers have little opportunity to do so. Investing in this change can impact not only teachers and parents, but also the children whose literacy development hinges on the effectiveness of such partnerships. 


\section{References}

Ames, C., Khoju, M., \& Watkins, T. (1993). Parent involvement: The relationship between school-to-home communication and parents' perceptions and beliefs. Baltimore, MD: Center on Families, Communities, Schools and Children's Learning.

Baker, L., Mackler, K., Sonnenschein, S., \& Serpell, R. (2001). Parents' interactions with their first-grade children during storybook reading and relations with subsequent home reading activity and reading achievement. Journal of School Psychology, 39(5), 415-438.

Ballantyne, K. G., Sanderman, A. R., \& McLaughlin, N. (2008). Dual language learners in the early years: Getting ready to succeed in school. National Clearinghouse for English Language Acquisition \& Language Instruction Educational Programs.

Beals, D., DeTemple, J., \& Dickinson, D. K. (1994). Talking and listening that support early literacy development of low-income children. In D. K. Dickinson (Ed.), Bridges to literacy: Children, families, and schools (pp. 241-263). Cambridge, MA: Blackwell.

Beaver, J., \& Carter, M. (2006). Developmental reading assessment. (2nd ed.) Boston, MA: Celebration Press.

Charmaz, K. (1983). The grounded theory method: An explication and interpretation. In R. M. Emerson (Ed.), Contemporary field research (pp. 109-126). Prospects Heights, IL: Waveland.

Clay, M. M. (2003). The early detection of reading difficulty. (3rd ed.) Auckland, New Zealand: Heinemann.

Dearing, E., Kreider, H., Simpkins, S., \& Weiss, H. B. (2006). Family involvement in school and low-income children's literacy performance: Longitudinal associations between and within families. Journal of Educational Psychology, 98, 653-66.

Delgado-Gaitan, C. (1990). Literacy for empowerment: The role of parents in children's education. New York, NY: Falmer Press.

Dickinson, D. K., \& Tabors, P. O. (2001). Beginning literacy with language: Young children learning at home and school. Baltimore: Brookes.

Dodd, A. W., \& Konzal, J. L. (2002). How communities build stronger schools: Stories, strategies and promising practices for educating every child. New York, NY: Palgrave Macmillan.

Eberly, J. L., Joshi, A., \& Konzal, J. (2007). Communicating with families across cultures: An investigation of teacher perceptions and practices. School Community Journal, 17(2), 726. 
Englund, M. M., Luckner, A. E., Whaley, G.J. L. \& Egeland, B. (2004). Children's achievement in early elementary school: Longitudinal effects of parental involvement, expectations, and quality of assistance. Journal of Educational Psychology, 96(4), 723-730.

Epstein, J. L., \& Sanders, M. G. (2006). Prospects for change: Preparing educators for school, family, and community partnerships. Peabody Journal of Education, 81(2), 81-120.

Flouri, E., \& Buchanan, A. (2004). Early father's and mother's involvement and child's later educational outcomes. British Journal of Educational Psychology, 74(2), 141-153.

Gay, L. R. \& Airasian, P. (2003). Educational research: Competencies for analysis and application (7th ed.) Upper Saddle River, NJ: Merrill.

Good, R. H., Kaminski, R. A. (2002). DIBELS oral reading fluency passages for first through third grades (Technical Report No. 10). Eugene, OR: University of Oregon Press.

Harcourt School Publishers. (2011). Harcourt Trophies. Orlando, FL: Author.

Heath, S. H. (1983). What no bedtime story means: Narrative skills at home and school. Language in Society, 11, 49-76.

Janus, M., \& Duku, E. (2007). The school entry gap: Socioeconomic, family, and health factors associated with children's school readiness to learn. Early Education and Development, 18(3), 375-403.

Jeynes, W. (2012). A meta-analysis of the efficacy of different types of parental involvement programs for urban students. Urban Education, 47(4), 706-742.

Jordan, G. E., Snow, C. E., \& Porche, M. V. (2000). Project EASE: The effect of a family literacy project on kindergarten students' early literacy skills. Reading Research Quarterly, 35(4), 524-546.

Landry, S. \& Smith, K. (2012). The family processes that support school readiness: Specific behaviors and contextual conditions that set this process in motion. In A. Booth \& A. C. Crouter (Eds.), Disparities in School Readiness (pp. 85-107). New York, NY: Psychology Press.

LeFevre, A. L., \& Shaw, T. V. (2011). Latino parent involvement and school success: Longitudinal effects of formal and informal support. Education and Urban Society, 44(6), 707-723.

McCarthey, S. J. (1997). Connecting home and school literacy practices in classrooms with diverse populations. Journal of Literacy Research, 29, 145-182. 
Moll, L., Amanti, C., Neff, D., \& González, N. (2005). Funds of knowledge for teaching: Using a qualitative approach to connect homes and classrooms. In Funds of Knowledge: Theorizing Practices in Households, Communities, and Classrooms (pp. 71-88). Mahwah, NJ: Lawrence Erlbaum Associates.

Morrow, L. M., \& Casey, H. K. (2004). A Professional development project with early literacy teachers: Partners in change. The Reading Teacher, 57(7), 662-668.

Morrow, L. M., Casey, H., \& Haworth, C. (2003). Staff development for early literacy teachers: A plan to facilitate change. In D. Barone \& L. M. Morrow (Eds.), Literacy and young children: Research based practice (pp. 3-22). New York, NY: Guilford Publications.

National Early Literacy Panel. (2008). Developing early literacy: Report of the National early literacy panel. Washington, DC: National Institute for Literacy.

National Governors Association Center for Best Practices \& Council of Chief State School Officers. (2010). Common core state standards. Washington, DC: Author.

O'Donnell, K. (2008). Parents' reports of the school readiness of young children from the national household education surveys program of 2007 (NCES 2008-051). Washington, DC: National Center for Education Statistics, Institute of Education Sciences, U. S. Department of Education.

Patton, M. Q. (2002). Qualitative research and evaluation methods (3rd ed.). Thousand Oaks, CA: Sage Publications.

Purcell-Gates, V. (1996). Stories, coupons, and the TV Guide: Relationships between home literacy experiences and emergent literacy knowledge. Reading Research Quarterly, 31(4), 406-428.

Rathvon, N. (2004). Early reading assessment: A practitioner's handbook. New York, NY: Guilford Press.

Sénéchal, M., \& LeFevre, J. (2014). Continuity and change in the home literacy environment as predictors of growth in vocabulary and reading. Child Development, 85(4), 1552-1568.

Sénéchal, M., \& LeFevre, J. (2002). Parental involvement in the development of children's reading skill: A 5-year longitudinal study. Child Development, 73, 445-460.

Sheldon, S. B., \& Epstein, J. L. (2005). School programs of family and community involvement to support children's reading and literacy development. In J. Flood \& P. Anders (Eds.), Literacy development of students in urban schools: Research and policy (pp. 107-138). Newark, DE: International Reading Association. 
Sheldon, S. B., \& Van Voorhis, V. L. (2004). Partnership programs in U. S. schools: Their development and relationship to family involvement outcomes. School Effectiveness and School Improvement, 15, 125-148.

Silinskas, G., Lerkkanen, M., Tolvanen, A., Niemi, P., Poikkeus, A., \& Nurmi, J. (2012). The frequency of parents' reading-related activities at home and children's reading skills during kindergarten and grade 1. Journal of Applied Developmental Psychology, 33(6), 302-310.

Steiner, L. M. (2014). A family literacy intervention to support parents in children's early literacy learning. Reading Psychology. DOI: 10.1080/02702711.2013.801215.

Taylor, D. \& Dorsey-Gaines, C. (1988). Growing up literate: Learning from inner-city families. Portsmouth, NH: Heinemann.

Thigpen, D., Freedberg, L. F., \& Frey, S. (2014). The power of parents: Research underscores the impact of parent involvement in school [Executive Summary]. EdSource. Retrieved from: http://edsource.org/wp content/publications/Power-of-Parents-Feb-2014.pdf

Turner, J. D., \& Edwards, P. A. (2009). Old tensions, new visions: Implications for teacher education programs, K-12 schools, and family literacy programs. In G. Li (Ed.), Multicultural Families, Home Literacies, and Mainstream Schooling (pp. 246-268). Albany, NY: SUNY Press.

United States Department of Education. (1996). Policy Guidance for Title I, Part A: Improving Basic Programs Operated by Local Educational Agencies. Retrieved from https://www2.ed.gov/legislation/ESEA/Title_I/parinv.html\#plan.

Valdéz, G. (1996). Con Respecto: Bridging the distances between culturally diverse families and schools. New York, NY: Teachers College Press.

Van Voorhis, F. L., Maier, M. F., Epstein, J. L., Lloyd, C. M., \& Leung, T. (2013). The impact of family involvement on the education of children ages 3 to 8: A focus on literacy and math achievement outcomes and social-emotional skills. MDRC. Retrieved from http://www.mdrc.org/sites/default/files/The_Impact_of_Family_Imvolvement_ES.pdf

Wade, B., \& Moore, M. (2000). A sure start with books. Early Years, 20(2), 39-46.

Wade, B., \& Moore, M. (1998). An early start with books: literacy and mathematical evidence from a longitudinal study. Educational Review, 50(2), 135-145.

Wells, G. (2004). Dialogic inquiry: Towards a sociocultural practice and theory of education. Cambridge, UK: Cambridge University Press. 
Whitehurst, G. J., Arnold, D. S., Epstein, J. N., Angell, A. L., Smith, M., \& Fischel, J. E. (1994). A picture book reading intervention in day care and home for children from low-income families. Developmental Psychology 30(5), 679-689.

Wigfield, A., Harold, R. D., Freedman-Doan, C., Eccles, J. S., Suk Yoon, K., Arbreton, A. J., Blumenfeld, P. C. (1997). Change in children's competence beliefs and subjective task values across the elementary school years: A three-year study. Journal of Educational Psychology, 89, 451-459.

Yaden, D. B., Jr., \& Paratore, J. (2003). Family literacy at the turn of the millennium: The costly future of maintaining the status quo. In J. Flood, D. Lapp, J. R. Squire, \& J. M. Jensen (Eds.), Handbook of research on teaching the English language arts $\left(2^{\text {nd }}\right.$ ed.) (pp. 532545). Mahwah, NJ: Erlbaum.

\section{Children's Literature}

Bunting, E. (1990). The Wednesday surprise. New York, NY: Clarion Books.

Ehlert, L. (1992). Moon rope/Un lazo a la luna. New York, NY: Random House.

Hoberman, M.A. (2001) Fathers, mothers, sisters, brothers: A collection of family

poems. Boston, MA: Joy Street Books.

Kindersley, B. (1997). Celebrations. New York, NY: DK Publishing.

Kinkade, S. (2006). My family. Watertown, MA: Charlesbridge.

Morris, A. (2000). Families. New York, NY: Harper Collins.

Numeroff, L. J. (1985). If you give a mouse a cookie. New York, NY: Harper \& Row.

Numeroff, L. J. (1987). If you give a pig a pancake. New York, NY: Harper \& Row.

Reiser, L. (1994). The surprise family. New York, NY: Greenwillow Books.

Sketch, R. (1998). Who's in a family? New York, NY: Tricycle.

Small, D. (1985). Imogene's antlers. New York, Scholastic. 


\section{Teacher Interview Questions}

\section{Appendix 1}

\section{Teacher Background}

1. How many years have you been working as a teacher? Describe your specialty and educational background.

General Teacher-Parent Communication

1. How often do you communicate with parents?

2. How often do you communicate with parents of students needing extra help?

3. How would you describe most of the communication that you have with parents: (1) mostly one-way communications where you inform parents about their child or other issues; (2) mostly two-way communications where there is information shared back and forth with parents; (3) or a combination of both?

4. What percentage of your students' parents or guardians regularly contact you?

5. How comfortable are you most of the time communicating with parents or guardians of your students?

6. How comfortable do you think most parents are communicating with you?

7. What are some roadblocks to communicating with parents or guardians of your students have you encountered?

8. What do you think are the best resources available for parents to get information that they can use in helping their children in school?

\section{School Resources}

1. Does your school have a policy concerning parent communication? Do you know the components?

2. In what ways can parents or guardians who work full time and have no flex-time get involved in their children's education? (Write notes; use vacation time; e-mail; attend sporting/extracurricular events; help with homework; visit before/after school)

3. In what ways does the administration/school support you in communicating with parents? Classroom Practices

1. What part of the curriculum do you think best brings in the backgrounds and interests of your students?

2. What ways do you think parents can most contribute to their children's successes in learning to read and write?

3. In what ways do you presently engage parents in their children's literacy learning? What were some of the successes? Barriers?

4. Do you (encourage/discourage) classroom visits by parents? Please explain: Attitudes and Beliefs about Parent Involvement

1. Besides the grades that are earned by their children, what would you say are the most important things parents need to know about their children's education or daily school activities? Please explain:

2. How often do you take parents' suggestions?

3. Would you say that you fully understand what parents expect from you as a teacher?

4. Do you think that parents fully understand what you expect from them? 